Aspirasi: Jurnal Masalah-Masalah Sosial | Volume 11, No. 1 Juni 2020

ISSN: 2086-6305 (print) ISSN: 2614-5863 (electronic)

doi: 10.22212/aspirasi.v11i1.1501

link online: http://jurnal.dpr.go.id/index.php/aspirasi/index

\title{
Penanggulangan Kemiskinan Perempuan melalui Strategi Keuangan Inklusif oleh Koperasi Mitra Dhuafa (KOMIDA)
}

\author{
Women's Poverty Alleviation through Inclusive Financial Strategies \\ by Koperasi Mitra Dhuafa (KOMIDA)
}

\section{Junius Fernando S. Saragih}

juniusfernandosaragih@gmail.com

Pascasarjana Ilmu Kesejahteraan Sosial

Fakultas Ilmu Sosial Ilmu Politik Universitas Indonesia

Jl. Prof. Dr. Selo Soemardjan, Pondok Cina, Beji, Kota Depok, Jawa Barat

Naskah diterima: 9 Desember 2019 | Naskah direvisi: 3 Juni 2020 | Naskah diterbitkan: 30 Juni 2020

\begin{abstract}
Poverty is still relatively high, especially among women. On the one hand the gap in work participation between men and women still occurs. On the other hand women have the opportunity to overcome the problems of poverty and their families with flexible work and do not interfere with the task of taking care of the household. Entrepreneurship is the right choice but needs to be accompanied by inclusive finance that brings capital closer to women. Inclusive finance is characterized by access to business capital financing without collateral, one-stop financial transactions, availability of financing that exceeds demand and increased financial literacy including saving habits and increasing financial management capabilities. It aims to describe and analyze the application of inclusive financial strategies in sustainable poverty reduction for women and to explain and analyze the impact of poverty reduction on low-income women and their families. The research method used is a qualitative approach with a descriptive type. The results show that financing can increase business interest and stimulate business development, increase income and strengthen the role of women in the welfare of their families. Poverty alleviation through an inclusive financial strategy is effective in increasing the economy, capacity and role of women in the welfare of the family. An adequate selection and monitoring system has a profound effect on this success.
\end{abstract}

Keywords: financial inclusion; financial literacy; poverty alleviation; sustainability; welfare

\begin{abstract}
Abstrak: Kemiskinan masih tergolong tinggi, khususnya di kalangan perempuan. Sementara kesenjangan partisipasi kerja antara laki-laki dan perempuan masih terjadi. Di sisi lain perempuan memiliki peluang untuk mengatasi masalah kemiskinannya dan keluarganya dengan pekerjaan yang fleksibel dan tidak mengganggu tugas mengurus rumah tangga. Berwirausaha adalah pilihan yang tepat, namun perlu diiringi dengan keuangan inklusif yang mendekatkan modal kepada perempuan. Keuangan inklusif ditandai dengan akses terhadap pembiayaan modal usaha tanpa agunan, transaksi keuangan satu pintu, ketersediaan pembiayaan yang melebihi permintaan, dan peningkatan literasi keuangan, meliputi kebiasaan menabung serta peningkatan kemampuan pengelolaan keuangan. Penelitian ini bertujuan menguraikan dan menganalisis penerapan strategi keuangan inklusif dalam penanggulangan kemiskinan perempuan serta dampaknya terhadap perempuan berpendapatan rendah dan keluarganya. Metode penelitian yang digunakan adalah pendekatan kualitatif dengan jenis deskriptif. Hasil menunjukkan bahwa pembiayaan mampu meningkatkan minat usaha dan memberi stimulan dalam pengembangan usaha, peningkatan pendapatan, serta memperkuat peran perempuan dalam menyejahterakan keluarganya. Penanggulangan kemiskinan melalui strategi keuangan inklusif efektif meningkatkan ekonomi,
\end{abstract}


kapasitas dan peran perempuan dalam menyejahterakan keluarga. Sistem seleksi dan monitoring yang memadai sangat besar pengaruhnya akan keberhasilan ini.

Kata Kunci: keuangan inklusif; literasi keuangan; penanggulangan kemiskinan; keberlanjutan; kesejahteraan

\section{Pendahuluan}

Bullock (2013) mengungkapkan 70\% orang miskin di dunia adalah perempuan. Di Indonesia sendiri, BPS (2018) mengungkapkan perempuan yang berada di bawah garis kemiskinan sebanyak $10,06 \%$ dari total jumlah perempuan di Indonesia. Sulit menyangkal tingginya kemiskinan di kalangan perempuan. Faktanya, akses pekerjaan belum sepenuhnya terbuka lebar. Terjadi kesen- jangan tingkat partisipasi kerja antara laki-laki dan perempuan. Dalam kurun waktu 2011-2019, BPS melansir Tingkat Partisipasi Angkatan Kerja (TPAK) laki-laki per tahun 2010 mencapai $83,76 \%$ dan turun menjadi $82,51 \%$ pada tahun 2017. Sementara TPAK perempuan nyaris tidak ada peningkatan signifikan, yaitu tahun 2010 hanya sebesar 51,76\% lalu turun menjadi 50,89\% pada 2017.

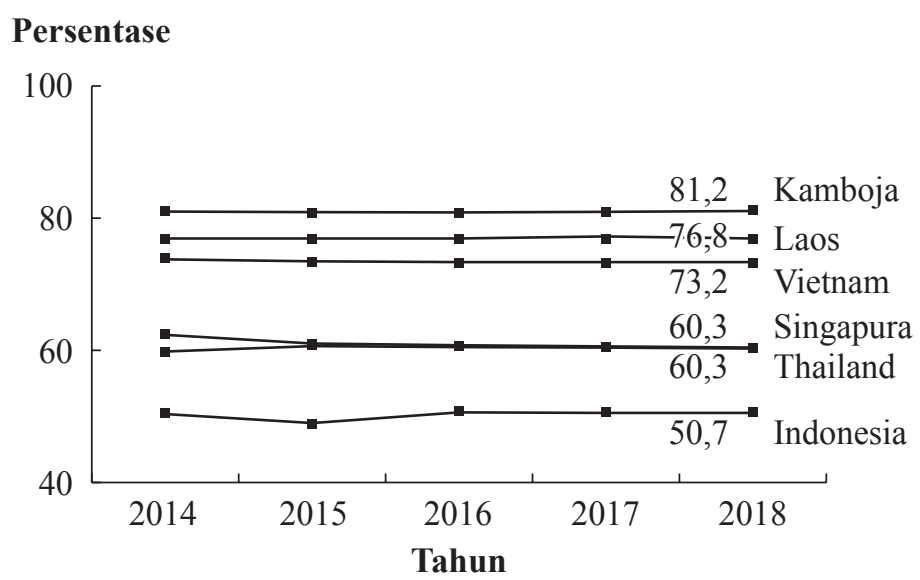

\section{Grafik 1. Tingkat Partisipasi Angkatan Kerja Perempuan di Asean Usia di Atas 15 Tahun, Tahun 2014-2018 \\ Sumber: World Bank, 2019, Diakses dari Tim Publikasi Katadata}

Merujuk grafik di atas, sejak tahun 2014 TPAK perempuan di Indonesia terendah di kawasan ASEAN. Padahal, menurut data BPS dan United Nation Population Fund (2018) terdapat 131,88 juta penduduk Indonesia yang berjenis kelamin perempuan. Hampir setengah dari total 265 juta jiwa penduduk Indonesia ini perlu diberdayakan agar keluar dari jeratan kemiskinan di tengah keterbatasan lapangan pekerjaan dan pembiayaan mikro yang belum sepenuhnya inklusif bagi kelompok paling miskin.

Kurang relevan hanya membicarakan melekatnya kemiskinan pada perempuan tanpa mengungkapkan perannya dalam menyejahterahkan keluarga. Perempuan kerap kali dituntut bisa bekerja dengan tetap bertanggung jawab meng-urus rumah tangganya. Pilihan rasional di tengah dwifungsi ini adalah memulai usaha di rumah dengan dukungan pembiayaan yang memadai sehingga akses modal memiliki andil besar menolong perempuan menanggulangi kemiskinan.

Abdulkadir dan Rilda (2000: 59) mengatakan bahwa unsur penting pemberian kredit adalah kepercayaan, agunan, jangka waktu, risiko, bunga, serta kesepakatan. Mayoritas perempuan miskin tidak memiliki aset untuk diagunkan dan dianggap berisiko dalam pengembalian pembiayaan. Itu sebabnya intervensi melalui kebijakan keuangan inklusif memang sangat dibutuhkan (Bank Indonesia, 2014).

Kodan dan Chhikara (2013) menemukan inklusi keuangan tidak saja berhasil meningkatkan pendapatan per kapita masyarakat, namun ti- 
ap kenaikan 1\% indeks keuangan inklusif berdampak pada penurunan $0,688 \%$ tingkat kemiskinan di India. Jiang, Tong, Hu, dan Wang (2019) menemukan keuangan inklusif sangat baik mendorong kewirausahaan para petani di China. Bahkan Bhatia dan Singh (2019) menemukan perempuan yang memperoleh kebijakan keuangan inklusif dari pemerintah memiliki kondisi sosial, politik, dan ekonomi yang lebih tinggi. Selanjutnya, Yaumidin, Suhodo, Yuniarti, dan Hidayatina (2017) menyimpulkan keterlibatan perempuan dalam keuangan mikro meningkatkan posisinya dalam rumah tangga karena akses terhadap pendapatan independen, kontrol atas tabungan, dan penggunaan kredit, membawa aset produktif ke ekonomi rumah tangga, serta mencari tambahan pendapatan bagi keluarga.

Komitmen terhadap keuangan inklusif sebagai upaya penanggulangan kemiskinan dan pencapaian kesejahteraan sosial telah dinyatakan Presiden Indonesia pada Konferensi Tingkat Tinggi (KTT) G-20 di Los Cabos, Meksiko tahun 2012 (Kementerian Keuangan, 2012). Sebelumnya, pada tahun 2009 anggota G-20 sudah menggaungkan pentingnya peningkatan akses keuangan bagi kelompok in the bottom of the pyramid untuk menolong mereka dari dampak krisis 2008. Terakhir pada tahun 2016, pemerintah secara resmi mengeluarkan Perpres No. 82 Tahun 2016 tentang Strategi Nasional Keuangan Inklusif.

Selain pemerintah, lembaga keuangan mikro melakukan strategi keuangan inklusif dengan menyalurkan pembiayaan berbasis kelompok perempuan seperti yang dilakukan oleh Koperasi Mitra Dhuafa (KOMIDA). KOMIDA memiliki 291 kantor cabang di seluruh Indonesia dan telah menyalurkan pembiayaan senilai $\mathrm{Rp} 8,62$ triliun kepada 745 ribu orang perempuan berpendapatan rendah. Sebagai lembaga keuangan mikro dengan sustainability yang baik, strategi keuangan inklusif yang dilakukan KOMIDA menarik untuk diteliti.

Pembiayaan bagi perempuan berpendapatan rendah perlu dipastikan tepat sasaran sehingga dibutuhkan sistem seleksi yang memadai. Di sisi lain, sustainability lembaga adalah kunci memperluas jangkauan penanggulangan kemiskinan. Peningkatan pendapatan perempuan bisa dilihat dari kapasitas pengembalian pembiayaan sehingga penting melakukan sis-tem monitoring pembiayaan. Dari sini kita bisa menemukan strategi keuangan inklusif yang efektif menanggulangi kasus kemiskinan di Indonesia, namun tetap memperhatikan sustainability program dan lembaga itu sendiri.

KOMIDA Cabang Cileungsi sebagai lokasi penelitian memiliki 2.845 anggota yang memperoleh pembiayaan dan layanan lain berupa simpanan, dana pensiun, serta pemberdayaan nonkeuangan. Cileungsi merupakan daerah industri yang lokasinya tidak jauh dari ibu kota yang mempunyai Taman Wisata Nasional Mekarsari, yaitu tempat pelestarian buah-buah tropika terbesar di dunia. Namun, kesejahteraan masyarakat di Cileungsi, khususnya perempuan, masih menjadi pekerjaan rumah pemerintah (Pemerintah Kecamatan Cileungsi, 2015). Menariknya, meskipun Cileungsi merupakan kawasan industri dan bercorak perkotaan, sistem yang digunakan oleh KOMIDA adalah Grameen Bank yang pada prinsipnya menyasar daerah-daerah pedesaan.

Berdasarkan masalah di atas, maka pertanyaan yang dirumuskan untuk penelitian ini adalah: (1) Bagaimana penerapan strategi keuangan inklusif yang dilakukan KOMIDA dalam penanggulangan kemiskinan perempuan dengan tetap menjamin keberlanjutan lembaga maupun program penanggulangan kemiskinan? (2) Bagaimana dampak penanggulangan kemiskinan melalui strategi keuangan inklusif yang dilakukan KOMIDA? Tujuan penelitian adalah menguraikan dan menganalisis penerapan strategi keuangan inklusif dalam penanggulangan kemiskinan perempuan yang berkelanjutan. Tujuan lainnya adalah menjelaskan dan menganalisis dampak penanggulangan kemiskinan tersebut terhadap perempuan berpendapatan rendah dan keluarganya.

Penelitian ini menggunakan pendekatan kualitatif untuk memahami fenomena secara alamiah dengan mengedepankan interaksi komunikasi yang mendalam antara peneliti dengan fenomena yang diteliti (Moleong, 2005). Analisisnya menggunakan teknik analisis kualitatif bersifat induktif dengan tahapan pengumpulan dan perekaman data, dilanjutkan deng- 
an penyeleksian dan pemrosesan data terdiri dari sortir, klasifikasi, pengkodean (open, axial, dan selective coding), lalu dilanjutkan dengan interpretasi dan elaborasi (Neuman, 2016: 560-570). Pemilihan informan menggunakan teknik purposive sampling, memilih 24 informan yang mengetahui penanggulangan kemiskinan perempuan melalui keuangan inklusif yang dilakukan KOMIDA. Informan tersebut meliputi: 1 orang Pengurus KOMIDA Pusat, 1 orang Manajer KOMIDA Cileungsi, 1 o-rang Asisten Manajer KOMIDA Cileungsi, 4 orang Staf Lapang KOMIDA Cileungsi, 2 orang Staf Community Development KOMIDA Pusat, 5 orang Ketua center/kelompok anggota KOMIDA, dan 10 anggota dan mantan anggota KOMIDA. Teknik pengumpulan data dilakukan dengan wawancara mendalam, observasi, dan studi dokumentasi.

\section{Upaya Penanggulangan Kemiskinan}

Suharto (2009: 138) mengungkapkan pengukuran kemiskinan dipengaruhi oleh perspektif income poverty di mana pendapatan menjadi salah satu indikator garis kemiskinan. Oleh karenanya, penanggulangan kemiskinan dapat dilakukan dengan meningkatkan pendapatan orang miskin. Sementara Todaro (2000: 28) melihat penanggulangan kemiskinan sebagai pembangunan ekonomi yang ditujukan kepada tiga nilai pokok, yaitu berkembangnya kemampuan masyarakat untuk memenuhi kebutuhan pokoknya, meningkatnya rasa harga diri masyarakat sebagai manusia, dan meningkatnya kemampuan masyarakat untuk memilih.

Ife (2013: 184) membagi pembangunan ekonomi kepada dua kategori, yaitu pendekatan konservatif dan pendekatan radikal. Salah satu pendekatan radikal yang bisa dilakukan adalah melalui kredit mikro (microfinance and microcredit). Kredit mikro yang paling terkenal dan dapat dicontohkan adalah Grameen Bank dari Bangladesh. Idenya memberikan pinjaman kecil yang digunakan untuk membeli peralatan sebagai pijakan awal mendirikan usaha kecil agar masyarakat keluar dari kemiskinan. Sementara Mainsah, Heuer, Kalra, dan Zhang (2004) menjelaskan penyaluran kredit dengan sistem Grameen Bank menggunakan mekanisme calon debitur mengajak beberapa calon debitur lain yang dianggap baik untuk kemudian membentuk kelompok debitur. Setiap anggota bertanggung jawab apabila terdapat salah satu anggota tidak mampu mengembalikan kredit. Mekanisme ini memberikan keuntungan bagi Grameen Bank karena meminimalkan biaya untuk menggali informasi tentang calon debitur yang dianggap layak memperoleh kredit. Calon debitur akan berusaha mencari calon debitur lain yang dianggap bisa dipercaya untuk diajak bergabung dalam kelompok debitur. Risiko semakin minim karena setiap anggota bertanggung jawab ketika salah satu anggota kelompok tidak mampu membayar angsuran pinjamannya.

Lembaga keuangan mikro memberikan pinjaman kepada masyarakat miskin dengan sistem tanpa jaminan sehingga memberikan kemudahan bagi orang miskin untuk mengakses kredit usaha. Namun, ada biaya yang harus dikeluarkan lembaga keuangan mikro dan nilainya tidaklah sedikit. Goldberg dan Palladini (2010: 41) mengatakan agar berhasil, lembaga keuangan mikro harus mampu memenuhi sejumlah biaya tetap dan biaya variabel, serta menjamin laba tertentu. Biaya termasuk biaya operasi, biaya dana, dan kerugian pinjaman yang diharapkan. Biaya operasi termasuk ruang kantor dan persediaan, remunerasi dan pelatihan karyawan, transportasi dan komunikasi, serta peralatan dan penyusutan bangunan.

Lembaga keuangan mikro perlu memikirkan keberlanjutan usaha sehingga tidak semata-mata memikirkan bagaimana menolong orang miskin, namun juga memperhatikan keberlanjutan lembaga dan program yang dijalankannya. Keberadaan lembaga keuangan mikro telah membantu orang miskin mengakses kredit tanpa agunan yang menolongnya memulai dan mengembangkan usaha serta meningkatkan pendapatan demi keluar dari kemiskinan. Mishra, Igwe, Lean, dan Megicks (2014) mengatakan keuangan mikro adalah salah satu cara untuk mendukung usaha mikro dan kecil, karena ia menempatkan kredit, tabungan, asuransi, dan layanan keuangan dasar lainnya dalam jangkauan masyarakat miskin setempat. Melalui lembaga keuangan mikro, orang miskin dapat mengakses pinjaman kecil, menerima pengiriman uang dari kerabat migran 
dan memperluas atau mempertahankan kegiatan pendapatan dan investasi mereka. Keberadaan lembaga keuangan mikro memberikan lebih banyak pilihan bagi orang miskin sehingga tidak terperangkap jebakan lintah darat.

\section{Strategi Keuangan Inklusif}

Penyaluran kredit kepada orang miskin sejatinya merupakan tujuan keuangan inklusif. Bank Indonesia (2014) mendefinisikan keuangan inklusif sebagai pendalaman layanan keuangan (financial service deepening) ditujukan bagi mereka yang berada in the bottom of the pyramid untuk memanfaatkan produk dan layanan keuangan formal, seperti saranamenyimpanuangyang aman (keeping), transfer, menabung, pinjaman, dan asuransi. Tidak sekadar menyediakan produk layanan yang sesuai, melainkan dikombinasikan dengan berbagai aspek. Jadi, tujuan keuangan inklusif adalah mendekatkan masyarakat kelas bawah pada modal yang sangat berguna untuk meningkatkan kesejahteraan.

Sarma (2012) mendefinisikan keuangan inklusif sebagai sebuah proses yang menjamin kemudahan akses, ketersediaan, dan kemanfaatan dari sistem keuangan formal untuk semua anggota entitas ekonomi. Lampiran Perpres No. 82 Tahun 2016 tentang Strategi Nasional Keuangan Inklusif memperkenalkan lima pilar strategi keuangan inklusif, yaitu edukasi keuangan, hak properti masyarakat, fasilitas intermediasi dan saluran distribusi keuangan, layanan keuangan pada sektor pemerintah, serta perlindungan konsumen. KOMIDA sebagai lembaga keuangan mikro tidak sekadar mendekatkan akses layanan keuangan kepada perempuan berpendapatan rendah, melainkan juga melakukan edukasi keuangan atau lebih dikenal dengan sebutan literasi keuangan. Bahkan lebih dari itu, KOMIDA juga melakukan pendampingan dan pemberdayaan yang bersifat nonkeuangan.

Berbagai studi menunjukkan bahwa literasi keuangan memiliki peran yang strategis untuk meningkatkan kemampuan pengelolaan keuangan individu. Modligiani dan Brumberg (1954) serta Friedman (1957, dalam Lusardi \& Mitchell, 2014) menjelaskan bahwa konsumen diposisikan untuk mengatur simpanan dan pengeluaran secara optimal agar memberikan manfaat sepanjang masa hidupnya. Studi lain yang dilakukan oleh Lusardi dan Mitchell (2007) mengindikasikan bahwa rumah tangga yang memiliki literasi keuangan yang rendah cenderung tidak merencanakan masa pensiunnya dan memiliki aset yang rendah.

Adams dan Rau (2011) menunjukkan bahwa pemahaman prinsip-prinsip dasar menabung, seperti compound interest mempunyai pengaruh langsung pada persiapan keuangan di hari tua. Boon, Yee, dan Ting (2011) juga menemukan bahwa individu yang memiliki literasi keuangan lebih siap dalam melakukan perencanaan keuangan pribadinya. Dalam penelitian lain, Carpena, Cole, Shapiro, dan Zia (2011) menemukan bahwa edukasi keuangan memengaruhi kesadaran dan sikap seseorang terhadap produk keuangan dan penggunaan berbagai instrumen perencanaan keuangan yang tersedia.

Penanggulangan kemiskinan melalui strategi keuangan inklusif juga perlu ditinjau dampaknya. Cohen (1984) mengelompokkan dampak ekonomi meliputi: (1) dampak terhadap pendapatan; (2) dampak terhadap aktivitas ekonomi; dan (3) dampak terhadap pengeluaran. Sementara Stynes (1997) mengelompokkan dampak ekonomi menjadi tiga yaitu (1) direct effect meliputi penjualan, kesempatan kerja, pendapatan pajak dan tingkat pendapatan; (2) indirect effect meliputi perubahan tingkat harga, perubahan mutu dan jumlah barang dan jasa, perubahan dalam penyediaan properti dan variasi pajak, serta perubahan sosial dan lingkungan; (3) induced effects, yaitu pengeluaran rumah tangga dan peningkatan pendapatan.

Sementaraitu, Sinaga (2004: 134) mengatakan bahwa dampak sosial ekonomi dapat dilihat dari dua sisi yaitu dampak positif dan dampak negatif. Dampak positif bisa meliputi meningkatnya kelayakan dan kenyamanan usaha, terbukanya kesempatan kerja dan perubahan status menjadi pedagang legal. Sebaliknya dampak negatif bisa meliputi menurunnya pendapatan, meningkatnya biaya operasional, melemahnya jaringan sosial, dan menurunnya kesempatan pedagang untuk ikut dalam kelompok-kelompok sosial nonformal.

Dengan demikian, strategi keuangan inklusif bisa dilihat dari dua poin penting, yaitu: (1) 
mendekatkan akses keuangan itu kepada kelompok masyarakat miskin; dan (2) mengedukasi mereka dalam pengelolaan keuangan yang dimiliki. Setidaknya ketika keduanya berjalan, dampak yang diharapkan berupa peningkatan pendapatan dan kesiapan keuangan di hari tua pun lebih mungkin untuk dicapai.

\section{Penanggulangan Kemiskinan Perempuan Melalui Keuangan Inklusif oleh KOMIDA}

Penanggulangan kemiskinan perempuan yang dilakukan oleh KOMIDA menggunakan strategi keuangan inklusif, yakni membuka akses perempuan berpendapatan rendah terhadap layanan keuangan, terutama pembiayaan tanpa agunan, serta meningkatkan literasi keuangan mereka. Di samping itu, pendampingan dan pemberdayaan nonkeuangan juga dilakukan di bawah koordinasi tim community development regional KOMIDA. Hanya saja, upaya ini baru bergerak dalam tataran penyuluhan dengan topik pendidikan, kesehatan, dan kewirausahaan.

Layanan keuangan yang disediakan meliputi simpanan dan pembiayaan. Simpanan KOMIDA terdiri dari simpanan wajib, tabungan sukarela, simpanan pensiun, dana risiko, dan tabungan hari raya. Simpanan wajib dan simpanan pensiun hanya bisa dicairkan setelah keluar dari keanggotaan. Sesuai dengan apa yang dikatakan Adams dan Rau (2011), upaya ini dilakukan untuk mempersiapkan hari tua. Dana risiko berfungsi sebagai asuransi. Manakala anggota meninggal, maka seluruh angsuran pembiayaan yang belum sempat dibayarkan dianggap lunas. Sementara bila suami anggota yang meninggal, 50\% dari pembiayaan dilunaskan. Simpanan sukarela dapat dicairkan kapan saja dan kerap dimanfaatkan anggota untuk membayar angsuran pengembalian ketika anggota mengalami kesulitan keuangan. Dana risiko, simpanan sukarela dan tabungan hari raya berusaha menjadikan anggota seperti dikatakan Boon, Yee, dan Ting (2011) lebih siap dalam melakukan perencanaan keuangan pribadinya.

Hal di atas menjadi upaya literasi keuangan yang mengedukasi perempuan untuk menabung sebagai jalan merencanakan keuangan di masa depan, meliputi antisipasi kebutuhan tak terduga, mempersiapkan pendidikan anak, dan perayaan hari besar agama. Kerajinan anggota dalam menabung dan jumlah saldo simpanan menjadi pertimbangan dalam peningkatan nominal pembiayaan di KOMIDA. Dengan demikian, mau tidak mau anggota dituntut meningkatkan kebiasaannya dalam menabung. Literasi keuangan juga dilakukan dengan cara meningkatkan kemampuan dasar pengelolaan keuangan, seperti menyisihkan pendapatan untuk simpanan, angsuran, dan kebutuhan sehari-hari, di samping juga meningkatkan trust terhadap lembaga keuangan.

Sementara produk pembiayaan yang disediakan oleh KOMIDA merupakan pembiayaan microfinance sebagaimana dikategorikan Ife (2013: 184) sebagai pendekatan radikal dalam pembangunan ekonomi. Ini bertujuan menanggulangi kemiskinan dengan memotivasi perempuan yang belum memiliki usaha untuk mendirikan usahanya, sementara bagi yang sudah memiliki usaha diberikan stimulan untuk mengembangkan usahanya demi memperoleh pendapatan yang lebih besar. Hal ini sangat erat kaitannya dengan perspektif income poverty yang dikatakan Suharto (2009: 138), di mana penanggulangan kemiskinan perempuan dapat diatasi dengan meningkatkan pendapatan mereka.

Perempuan yang memperoleh pembiayaan wajib hadir dalam pertemuan center yang diselenggarakan setiap minggu dan bersedia dimonitor penggunaan pembiayaannya. Pertemuan center merupakan pertemuan mingguan berdurasi kurang dari 30 menit yang mempertemukan petugas lapang dengan dua atau lebih kelompok perempuan untuk melakukan transaksi keuangan. Kehadiran dalam pertemuan center menjadi salah satu penilaian prestasi anggota dan dijadikan syarat pengajuan pembiayaan selanjutnya. Nominal pembiayaan awal adalah senilai Rp2.000.000 dan akan meningkat pada pembiayaan tahap dua dan selanjutnya. Nominal ini mampu mendirikan usaha baru dalam skala kecil dan menengah atau mengembangkan usaha berskala kecil menjadi skala menengah. Pada kasus lain justru mampu menambah jumlah usaha yang dimiliki menjadi dua atau lebih jenis usaha.

Pembiayaan yang disediakan oleh KOMIDA terdiri dari pembiayaan umum atau modal usaha, 
pembiayaan dana talangan pendidikan dan pembiayaan sanitasi. Sebagaimana dikatakan Soelaksono (2005: 10) bahwa mayoritas masyarakat berpendapatan rendah, di dalamnya juga terdapat perempuan-perempuan yang sulit mengakses pembiayaan dari bank. Eksistensi lembaga keuangan mikro seperti KOMIDA seolah memuaskan kehausan pembiayaan modal usaha. Tidak heran, berdasarkan temuan lapangan, mayoritas perempuan yang bergabung menjadi anggota KOMIDA didasari ketertarikan pada tawaran pembiayaan modal usaha.

Namun, perempuan berpendapatan rendah yang ingin menjadi penerima manfaat strategi keuangan inklusif dari KOMIDA wajib melewati seleksi keanggotaan. Tujuannya adalah agar pemberian keuangan bisa dilakukan tepat sasaran, yaitu kepada anggota yang berkomitmen tinggi untuk keluar dari kemiskinannya. Anggota yang tidak berkomitmen bukan saja tidak mampu keluar dari kemiskinan, namun juga berpotensi gagal mengembalikan pembiayaan. Macetnya pengembalian pembiayaan membuat perempuan berpendapatan rendah lain kehilangan kesempatan memperoleh pembiayaan dari KOMIDA. Jika ini terjadi pada skala besar, dana pembiayaan yang tersedia akan habis terkuras sia-sia dan mengancam sustainability lembaga keuangan mikro dengan segala bentuk program penanggulangan kemiskinannya.

Perlu diingat, lembaga keuangan mikro seperti KOMIDA juga menjalankan fungsi intermediasi keuangan, yakni membeli surplus dana dari pemerintah, bank, sektor swasta, maupun individu untuk disalurkan kepada perempuan berpendapatan rendah yang membutuhkan. Itu artinya pembiayaan yang disalurkan merupakan dana yang dikelola oleh KOMIDA sehingga wajib dikembalikan kepada pemilik dana pada jangka waktu tertentu. Dengan demikian, diperlukan sistem monitoring yang efektif agar tidak terjadi penyalahgunaan pembiayaan dan memastikan pengembalian pembiayaan berjalan lancar.

Pembiayaan yang berhasil dikembalikan oleh penerima manfaat akan disalurkan kembali kepada perempuan lain yang membutuhkan dan demikianlah dilakukan secara berkelanjutan sampai dana tersebut jatuh tempo untuk dikembalikan kepada unit surplus yang memper- cayakan dananya pada KOMIDA. Sistem seleksi dan monitoring anggota yang baik membuat KOMIDA menjadi salah satu lembaga keuangan mikro yang kuat secara kelembagaan. KOMIDA terbukti memiliki 291 kantor cabang di seluruh Indonesia dan telah menyalurkan pembiayaan sebesar Rp8,62 triliun kepada 745 ribu orang anggota.

Salah satu indikator keuangan inklusif menurut Sarma (2012) adalah kemudahan akses keuangan. KOMIDA melakukannya dengan cara menyalurkan pembiayaan tanpa agunan. Bahkan sekalipun anggota tidak mampu mengembalikan pembiayaan, tak satupun barang miliknya akan disita sebagai ganti rugi. Sistem penagihan dilakukan secara persuasif dan sabar menunggu itikad baik anggota mengembalikan pembiayaan yang telah diterimanya. Namun, selama ini hanya sedikit anggota yang mangkir dalam pengembalian pembiayaan dikarenakan adanya sistem seleksi yang ketat, monitoring penggunaan pembiayaan, serta sistem kekeluargaan yang dibangun sejak awal.

Mekanisme pengembalian pembiayaan dilakukan dengan membayar angsuran mingguan pada saat pertemuan center. Jika terdapat anggota yang tidak hadir dan tidak membayar angsuran, seluruh anggota kelompok wajib bertanggung jawab membayar angsuran anggota yang bersangkutan dengan cara tanggung renteng. Tanggung renteng di KOMIDA mewajibkan seluruh anggota kelompok untuk menanggung angsuran pengembalian pembiayaan salah seorang anggota yang tidak hadir pada pertemuan center atau tidak mampu membayar.

Berdasarkan temuan lapangan, kendati tanggung renteng merupakan kewajiban yang sudah disepakati sejak pengesahan anggota, namun biasanya hanya bertahan diterapkan sebanyak tiga kali angsuran saja karena dianggap sangat membebani. Penagihan ke rumah anggota yang mangkir tetap harus dilakukan secara persuasif dan mendiskusikan solusi terbaik untuk mengatasi masalah anggota tersebut. Sistem tanggung renteng ditujukan untuk memastikan kelancaran pengembalian pembiayaan, namun sistem ini tidak sepenuhnya efektif karena tidak mungkin diterapkan secara paksa. Alih-alih anggota yang mangkir mendapat hukuman, justru 
anggota yang lancarlah yang dibebani melakukan tanggung renteng. Jelas hal ini menciptakan ketidakadilan bagi anggota yang sudah baik. Beberapa di antara mereka akhirnya memilih keluar dari keanggotaan untuk menghindari kewajiban tanggung renteng. Kendati demikian, sistem tanggung renteng tetap dipertahankan karena setidaknya mampu membuat anggota kelompok enggan tidak membayar angsuran karena tidak tega teman sekelompoknya harus menanggung beban. Meskipun hanya efektif berjalan maksimal tiga kali, angsuran itu sudah sangat membantu dalam memastikan pengembalian pembiayaan karena telah mengurangi angsuran yang perlu ditagih kepada anggota bermasalah.

Keuangan inklusif juga dilakukan KOMIDA dengan menyederhanakan sistem pengajuan dan pencairan pembiayaan serta mengefisienkan jarak, waktu dan biaya dalam melakukan transaksi keuangan. Pengajuan pembiayaan dilakukan dalam satu kali pertemuan center hanya dengan satu formulir. Pengajuan ini disertai dengan lampiran rincian rencana penggunaan pembiayaan ditempelkan pada formulir pengajuan dan menjadi acuan monitoring penggunaan pembiayaan. Pembiayaan dicairkan pada pertemuan center minggu selanjutnya dan dilanjutkan monitoring penggunaan pembiayaan dengan mengunjungi lokasi usaha anggota. Pada pembiayaan tahap pertama, masing-masing anggota memperoleh Rp2.000.000. Nominal pembiayaan ini akan ditingkatkan pada pengajuan tahap kedua dan selanjutnya dengan mempertimbangkan catatan prestasi anggota. Catatan prestasi merupakan pencatatan secara berkala meliputi tingkat kehadiran anggota, kelancaran angsuran, peningkatan usaha dan total simpanan yang dimiliki anggota tersebut.

Efisiensi jarak, waktu, dan biaya ditandai dengan transaksi keuangan satu pintu pada pertemuan center yang lokasinya berdekatan dengan rumah anggota. Penentuan lokasi didasarkan pada kesepakatan masing-masing anggota. Petugas lapang KOMIDA wajib mengunjungi lokasi pertemuan center sesuai jadwal yang sudah disepakati setiap minggunya. Anggota tidak perlu memikirkan jarak tempuh menuju kantor cabang. Tentunya ini menghemat waktu dan biaya, selain itu keamanan transaksi juga terjamin. Transaksi keuangan menyesuaikan dengan kemampuan anggota, di mana pembukaan rekening minimal Rp3.000 dan jumlah transaksi minimal Rp500.

Sarma (2012) mengatakan keuangan inklusif juga bisa dilihat dari ketersediaan dan kemanfaatan dari sistem keuangan formal untuk semua anggota entitas ekonomi. KOMIDA menyediakan sistem keuangan formal bagi perempuan berpendapatan rendah dan miskin. Fasilitas simpanan dan asuransi bermanfaat untuk mempersiapkan diri dalam menghadapi tantangan keuangan di masa depan, sementara pembiayaan berguna untuk mendukung usaha anggota dalam mencari keuntungan dan meningkatkan pendapatan. Ketersediaan pembiayaan juga jauh lebih besar dari permintaan di lapangan sehingga tidak ada alasan perempuan berpendapatan rendah yang membutuhkan pembiayaan mengalami kesulitan dalam mengakses pembiayaan dari KOMIDA. Hal ini terbukti dari masih tingginya tuntutan penambahan jumlah anggota di masing-masing cabang untuk merespons besarnya dana yang tersedia dan belum tersalurkan.

\section{Seleksi Penerima Manfaat Strategi Keuangan Inklusif}

Bank Indonesia (2014) mendefinisikan kebijakan keuangan inklusif sebagai bentuk pendalaman layanan keuangan bagi masyarakat in the bottom of the pyramid. Perlu dipastikan penerima manfaat strategi keuangan inklusif dari KOMIDA, termasuk masyarakat kelas bawah. Satu-satunya cara memastikannya adalah menciptakan sistem seleksi yang ketat dan akurat. Selain bisa menciptakan keuangan inklusif yang tepat sasaran, sistem seleksi ini memilah calon penerima manfaat berdasarkan keseriusan dan komitmennya untuk keluar dari kemiskinan.

Seleksi penerima manfaat strategi keuangan inklusif yang dilakukan KOMIDA dimulai sejak proses awal penentuan wilayah sasaran yang dianggap potensial dengan mempertimbangkan aksesibilitas, kepadatan penduduk, dan usaha yang berkembang di wilayah tersebut. Semakin mudah akses wilayah, maka semakin besar peluang wilayah tersebut disetujui. Akses wilayah yang mudah memungkinkan petugas lapang 
mengelola waktu dengan lebih baik sehingga ia bisa mengunjungi semua pertemuan center yang ada di bawah tanggung jawabnya. Seorang petugas lapang wajib mengunjungi 5 sampai dengan 8 pertemuan center sehari sehingga lokasi masing-masing pertemuan center idealnya saling berdekatan. Namun, tidak menutup kemungkinan wilayah dengan akses yang sulit tetap disetujui sebagai wilayah sasaran, dengan catatan wilayah tersebut memiliki potensi lain yang bisa mengimbangi tantangan aksesibilitas yang ada. Untuk meminimalisir persoalan, rekrutmen staf lapang baru dilakukan. Secara tidak langsung, hal ini sekaligus bisa membuka peluang untuk memperluas wilayah sasaran.

Kepadatan penduduk perlu dipertimbangkan untuk melihat ada tidaknya peluang usaha yang berbanding lurus dengan kebutuhan pembiayaan. Jenis usaha yang berkembang dianalisis kira-kira berapa besar nominal pembiayaan yang sesuai untuk pelaku usaha mikro kecil dan menengah. Setelah itu, petugas lapang berkoordinasi dengan pemerintah, lalu melakukan pendekatan dengan warga di wilayah tersebut.

Calon anggota potensial dikunjungi door to door, diberikan brosur sekaligus dijelaskan layanan KOMIDA. KOMIDA bisa saja bersaing dengan beberapa lembaga keuangan mikro lainnya, khususnya lembaga keuangan mikro dengan pembiayaan berbasis kelompok perempuan. Calon anggota berpeluang memilih lembaga keuangan yang dianggap lebih menguntungkan. Ada kemungkinan mereka memanfaatkan layanan jasa keuangan dari beberapa lembaga keuangan mikro sekaligus. Hal ini berisiko dalam pengembalian pembiayaan, selain justru menciptakan budaya konsumtif, memupuk ketergantungan, serta bisa membawa mereka ke dalam jebakan utang. Pada praktiknya, terdapat anggota KOMIDA yang memanfaatkan pembiayaan dari dua lembaga keuangan sekaligus. Pemanfaatan pembiayaan dari lembaga lain dilakukan setelah menerima pembiayaan dari KOMIDA. Namun, karena pengembalian pembiayaan tetap lancar dan tidak ada kendala, anggota yang melakukan hal seperti ini tidak dipermasalahkan.

Calon anggota yang tertarik diundang melakukan pertemuan umum untuk mendeng- arkan sosialisasi program KOMIDA sebelum memutuskan bergabung menjadi anggota. Pengambilan keputusan didasarkan pada kesadaran sendiri. Namun demikian, pengambilan keputusan tetap melibatkan suami yang bersangkutan dan persetujuan suami memang menjadi syarat keanggotaan. Syarat lainnya adalah bersedia hadir pada pertemuan center dan bersedia dikunjungi rumah atau lokasi usahanya dalam rangka monitoring penggunaan pembiayaan dan pencatatan prestasi.

Tahapan selanjutnya adalah pembentukan kelompok. Kendati pembiayaan ini berbasis kelompok, namun penggunaan pembiayaan tetap bersifat personal. Fungsi kelompok terlihat pada saat pengajuan dan pencairan pembiayaan, yaitu harus melalui persetujuan seluruh anggota kelompok. Apabila terdapat anggota yang tidak hadir dan tidak mampu membayar angsuran, seluruh anggota kelompok wajib tanggung renteng atau menanggung angsuran pengembalian pembiayaan anggota tersebut. Untuk menghindari tanggung renteng, masingmasing anggota diminta saling mengawasi dan mengingatkan agar tidak terjadi kemacetan pengembalian pembiayaan.

Sistem tanggung renteng membuat anggota lebih selektif pada saat pembentukan kelompok. Mereka bisa mengedepankan rasa saling mengenal dan saling percaya. Dengan demikian, rumah masing-masing anggota kelompok wajib berdekatan, namun tidak diperkenankan memiliki hubungan darah. Anggota kelompok merupakan penduduk asli wilayah tersebut mengacu pada KTP. Selain itu, anggota kelompok harus bersedia mengikuti Latihan Wajib Kelompok. Hal ini penting mengingat ketidakhadiran satu anggota kelompok saja bisa membatalkan pengesahan seluruh anggota dalam kelompok tersebut.

Setelah kelompok terbentuk, petugas lapang melakukan uji kelayakan ke rumah masing-masing calon anggota. Uji kelayakan dilakukan dengan mewawancarai calon anggota dan suaminya untuk memotret kondisi sosial ekonominya. Data yang dikumpulkan adalah kondisi rumah, dan aset rumah tangga, serta pendapatan per kapita anggota keluarga di rumah tersebut. Data ini digunakan untuk memastikan calon anggota merupakan perempuan berpendapatan rendah 
sehingga layak memperoleh layanan keuangan dari KOMIDA. Secara nasional, KOMIDA telah menentukan standar pendapatan minimum calon penerima manfaat, yaitu maksimal berpendapatan Rp1.000.000. Namun demikian, tidak menutup kemungkinan calon anggota yang berpendapatan di atasnya lulus menjadi penerima manfaat. Calon anggota yang berpendapatan di atas Rp1.000.000 menjadi prioritas kedua untuk diluluskan ketika tidak ada lagi calon anggota yang membutuhkan.

Dalam uji kelayakan, pertimbangan manajer cabang juga sangat menentukan. Manajer berhak mengunjungi kembali rumah calon anggota secara acak untuk memvalidasi hasil wawancara. Manajer berdiskusi dengan petugas lapang, mempertimbangkan, menganalisis lalu memutuskan calon anggota mana yang dianggap layak maju ke tahapan selanjutnya. Standar pendapatan minimum yang ditentukan oleh KOMIDA pusat juga tidak selalu menjadi acuan, mengingat tingkat perekonomian masingmasing wilayah tidak bisa diseragamkan. Peran manajer jauh lebih dominan dalam pengambilan keputusan sehingga memungkinkan lahirnya subjektivitas.

Setelah melewati uji kelayakan, calon anggota mengikuti Latihan Wajib Kelompok (LWK) sebagai sarana capacity building sebelum memperoleh layanan keuangan. Calon anggota dibekali pengetahuan tentang koperasi, sistem kerja, serta hak dan kewajiban anggota. Mereka diajari merancang rencana penggunaan pembiayaan untuk meningkatkan kapasitas penggunaan keuangan di masa depan. Selain itu, ditanamkan juga nilai-nilai kebersamaan, kedisiplinan dan tanggung jawab pada diri mereka.

Pada hari terakhir, manajer melakukan uji pengesahan kelompok dengan catatan kelompok tersebut telah menguasai 50\% materi, selalu hadir selama LWK, bertanggung jawab menyimpan tabungan kelompok, serta menilai kemampuan membuat rincian penggunaan pembiayaan. Kelompok yang lulus diminta mengisi formulir keanggotaan dan dinyatakan sah menjadi anggota KOMIDA. Setiap anggota berhak menerima pembiayaan pertama sebesar Rp2.000.000 dengan kewajiban membayar simpanan wajib sebesar $1 \%$, simpanan pensiun dan dana risiko masing-masing $1 \%$ dari jumlah pembiayaan yang diterima. Pada pengajuan tahap kedua dan seterusnya, nominalnya meningkat Rp500.000 sampai dengan Rp1.000.000. Selang seminggu setelah menerima pembiayaan, lokasi usaha anggota dikunjungi petugas lapang dalam rangka monitoring penggunaan pembiayaan.

Secara prosedur, sistemseleksiyangdilakukan oleh KOMIDA merupakan sistem seleksi yang ketat dan akurat untuk menghasilkan anggota yang serius dan berkomitmen menerima manfaat dari program pemberdayaan KOMIDA. Jika tidak sungguh-sungguh membutuhkan, calon anggota tidak mungkin sabar dan setia mengikuti setiap prosedur yang disediakan. Di sisi lain, pribadi yang konsumtif dan hanya ingin memanfaatkan pembiayaan atau tidak bersungguh-sungguh ingin keluar dari kemiskinan sudah lebih dulu tersingkir setidaknya pada saat proses pembentukan kelompok, uji kelayakan atau uji pengesahan kelompok. Dengan demikian, sistem seleksi ini memang efektif, tidak saja memastikan penerima manfaat adalah perempuan berpendapatan rendah atau miskin, melainkan juga memilih yang benarbenar berkomitmen keluar dari kemiskinannya.

\section{Pentingnya Monitoring dalam Strategi Keuangan Inklusif KOMIDA}

KOMIDA melakukan monitoring dengan dua metode, yakni monitoring mingguan di pertemuan center dan monitoring saat kunjungan ke rumah atau lokasi usaha anggota. Dengan monitoring, petugas lapang dapat mengetahui perkembangan anggota sejak awal diberikan pembiayaan. Pada pertemuan center, petugas lapang bertanggung jawab dalam transaksi keuangan, transfer pengetahuan, peningkatan wawasan, pencatatan prestasi, serta pengawasan pengembalian pembiayaan anggota. Mengingat lokasi pertemuan center berdekatan dengan rumah anggota, maka anggota bisa saling mengingatkan, saling mengajak hadir, serta mem bayar angsuran pada pertemuan center.

Pertemuan center menjadi kesempatan petugas lapang menanyakan perkembangan usaha anggota, memberi solusi untuk masalah yang sedang dihadapi anggota, sekaligus memotivasi anggota agar rajin menabung demi mempersiapkan masa depan. Pertemuan center juga mengefektifkan penerapan sistem tanggung 
renteng. Di pertemuan center-lah petugas lapang leluasa menagih komitmen tanggung renteng manakala terdapat anggota yang tidak hadir dan tidak mampu membayar angsuran. Hal ini dilakukan sambil mengingatkan anggota bahwa komitmen tanggung renteng merupakan catatan prestasi kelompok sebagai syarat memperoleh pembiayaanmikrobisnis, yaitu pembiayaan senilai Rp15 juta yang bisa diperoleh anggota.

Catatan prestasi merupakan salah satu wujud monitoring yang bisa menggambarkan perkembangan anggota. Dari catatan prestasi ini petugas lapang juga mengetahui anggota yang sedang bermasalah sehingga dapat segera dicarikan jalan keluar untuk membantu masalahnya. Pertemuan center juga merupakan sarana pemberdayaan nonkeuangan, yaitu penyuluhan pendidikan, kesehatan, dan kewirausahaan. Tujuannya untuk mengingatkan pentingnya pendidikan bagi anak, menjaga kesehatan, dan tips pengembangan usaha.

Selain monitoring dalam pertemuan center, juga dilakukan kunjungan ke lokasi usaha anggota untuk memastikan pemanfaatan pembiayaan sudah sesuai dengan rencana penggunaan pembiayaan yang dibuat pada saat pengajuan. Dari sini dapat dinilai tanggung jawab dan komitmen anggota untuk keluar dari kemiskinan. Hasil monitoring menemukan bahwa tidak semua pembiayaan dimanfaatkan untuk keperluan usaha. Dari total pembiayaan, $30 \%$ dimanfaatkan untuk keperluan sehari-hari, sisanya digunakan untuk keperluan usaha. Hal ini bisa terjadi karena nominal pembiayaan yang jauh lebih besar dibandingkan kebutuhan riil usaha mayoritas anggota yang bergerak di sektor mikro kecil dan menengah. Namun, selama angsuran pengembalian pembiayaan lancar dan usaha tetap berjalan, KOMIDA tidak mempermasalahkannya. KOMIDA menganjurkan penggunaan pembiayaan hanya untuk usaha. Tidak ada anggota yang mendapat sanksi karena penggunaan pembiayaan untuk keperluan sehari-hari.

Monitoring yang dilakukan oleh petugas lapang sifatnya terbatas. Komitmen dan tanggung jawab anggota adalah kunci keberhasilan penanggulangan kemiskinan melalui keuangan inklusif. Pengawasan ketat tidak akan ideal karena dikhawatirkan akan menghambat kreativitas dan kemandirian. Berdasarkan temuan lapangan, seorang anggota mengisahkan dirinya yang tidak terlena dengan nominal pembiayaan yang lebih besar dari kebutuhan usahanya. Ia berusaha memaksimalkan pembiayaan dengan memulai usaha baru yang sesuai dengan keahliannya. Sebelumnya ia hanya berjualan gorengan, namun pada pembiayaan kedua, anggota tersebut memanfaatkan setengah dari pembiayaan untuk membeli mesin jahit. Kini ia memiliki dua jenis usaha, yaitu sebagai penjual gorengan dan penjahit. Ini seperti yang dikatakan Todaro (2000: 28) bahwa keberhasilan pembangunan ekonomi bisa dilihat dari meningkatnya kemampuan masyarakat untuk memilih (freedom of servitude). Dengan nominal pembiayaan yang besar, perempuan berpendapatan rendah memiliki pilihan yang lebih banyak untuk membuka peluang seluas-luasnya dalam rangka meningkatkan pendapatan dan keluar dari kemiskinan.

Sementara untuk mengukur perkembangan usaha pasca pembiayaan serta mengukur keberhasilan upaya penanggulangan kemiskinan melalui keuangan inklusif, KOMIDA memiliki instrumen Progress Out of Poverty Index (PPI) yang sudah menjadi bagian dari Standar Operasional Prosedur (SOP) lembaga keuangan ini. PPI merupakan alat untuk mengetahui perubahan ekonomi dan sosial anggota pada periode tertentu. Dari sini dilihat kemampuan anggota untuk keluar dari garis kemiskinan atau masih dalam proses keluar dari kemiskinan. Monitoring menggunakan PPI dilakukan oleh petugas lapang dengan mengunjungi secara langsung lokasi usaha atau rumah anggota dan mewawancarai mereka tanpa memberi tahu bahwa tujuannya untuk mengukur tingkat kemiskinan.

\section{Dampak Penanggulangan Kemiskinan Anggota KOMIDA Cabang Cileungsi}

Berdasarkan hasil temuan lapangan, penanggulangan kemiskinan melalui keuangan inklusif terhadap anggota KOMIDA di Cabang Cileungsi mampu mengatasi kendala keterbatasan modal usaha yang selama ini menghambat minat usaha. Perkembangan ekonomi mulai teratasi dengan pembiayaan tanpa agunan. Pembiayaan 
menghasilkan apa yang disebut Stynes (1997) sebagai direct effect meliputi penjualan, kesempatan kerja, dan tingkat pendapatan. Selain itu, pembiayaan juga menghasilkan indirect effect meliputi perubahan tingkat harga, perubahan mutu dan jumlah barang. Kesempatan kerja ada karena modal memberdayakan anggota memulai usaha.

Strategi keuangan inklusif juga berdampak pada peningkatan dan perkembangan ekonomi. Peningkatan usaha anggota yang berusaha warung terlihat dari bertambahnya barang yang dijual. Mereka yang sebelumnya hanya berjualan sembako biasa kini mulai berjualan beras dan air kemasan galon. Selain itu, jumlah pembelinya meningkat serta bangunan warungnya semakin membaik. Anggota yang berusaha rongsok bersama suaminya mampu membeli rongsok lebih banyak sehingga lebih banyak pengepul di lingkungan sekitarnya yang merasa terbantu. Anggota yang berjualan ayam potong kini bisa membeli lebih banyak ayam dan menjualnya secara keliling menggunakan sepeda motor. Ada juga anggota yang berjualan nasi keliling mulai bisa menerima pesanan nasi kotak untuk acara. Anggota yang sebelumnya hanya berjualan gorengan termotivasi untuk menambah usaha baru, yakni membuka jasa menjahit untuk mengisi waktu luang dan memaksimalkan bakat yang dimilikinya. Sementara anggota yang memiliki usaha kredit barang berkesempatan membeli barang baru, lalu menjualnya lagi secara kredit sambil menunggu tenggat waktu pembayaran dari konsumen.

Perkembangan usaha berdampak pada peningkatan pendapatan keluarga. Hal ini mempermudah dalam pemenuhan kebutuhan sehari-hari. Seorang anggota yang berusaha kredit pakaian dan sudah lima kali menerima pembiayaan menuturkan adanya peningkatan pendapatan yang sebelumnya pada kisaran Rp200.000 sampai dengan Rp300.000 meningkat menjadi minimal Rp500.000 tergantung dari banyaknya konsumen. Anggota lain yang memiliki usaha jualan pakaian keliling dan sudah menerima pembiayaan sebesar Rp5.000.000 juga mengisahkan peningkatan keuntungan dari sebelum bergabung menjadi anggota KOMIDA hanya Rp150.000/minggu menjadi Rp400.000/ minggu. Anggota ini dapat membantu suaminya yang bekerja sebagai juru masak untuk memenuhi kebutuhan keluarga dengan tiga anak, yakni sebesar Rp800.000/minggu.

Tabungan anggota berguna untuk mempersiapkan biaya sekolah anak dan membiayai perayaan hari raya. Hal ini sesuai dengan apa yang disampaikan oleh salah seorang anggota bahwa ketika ada untung besar, maka ia memilih untuk menabung. Tabungannya sudah lumayan jumlahnya dan diambil pada saat lebaran atau ketika ada kebutuhan mendadak. Anggota lain menjelaskan bahwa dirinya bisa menabung sedikit demi sedikit. Ketika keuntungan sudah dialokasikan untuk keperluan sehari-hari dan angsuran mingguan, namun masih terdapat sisa, maka sisa tersebut akan ditabung.

Sementara dampak terhadap kapasitas diri terlihat dari meningkatnya motivasi kerja. Seorang anggota mengatakan lebih antusias menjalankan usahanya karena tidak lagi pusing memikirkan modal untuk berjualan sehari-hari. Anggota lain mengatakan menjadi lebih mandiri dalam memenuhi kebutuhan keluarga, tanpa harus meminta dari suami. Anggota menjadi lebih percaya diri karena semakin berdaya membantu suami memenuhi kebutuhan keluarga. Dampak positif lainnya adalah anggota memiliki kesempatan bersilaturahmi dengan anggota lain.

Literasi keuangan anggota membaik. Hal ini tergambar dari keterampilan anggota mengelola keuangan, yakni membagi alokasi keuntungan usaha menjadi tiga bagian meliputi pemenuhan kebutuhan sehari-hari, angsuran mingguan, dan tabungan. Seorang anggota menjelaskan bahwa dirinya belum pernah mengalami kesulitan dalam membayar angsuran pembiayaan karena selalu mengutamakan penyisihan keuntungan untuk angsuran mingguan, lalu sisanya dimanfaatkan untuk keperluan sehari-hari. Anggota lain juga mengakui bahwa ada perubahan pada dirinya sebelum dan setelah menjadi anggota. Sebelumnya, semua uang yang ia peroleh digabungkan menjadi satu, namun setelah menjadi anggota KOMIDA, keuntungan yang diperoleh selalu dipisah untuk angsuran mingguan, belanja dan jika masih ada sisa, maka sisanya akan ditabung. 
Namun, masih ada anggota yang belum memiliki catatan khusus mengenai peningkatan penghasilan secara berkala. Hal ini terlihat dari jawaban beberapa anggota yang tidak bisa menjelaskan perkembangan pendapatannya secara detail. Dampak lain adalah meningkatnya trust terhadap lembaga keuangan. Anggota memilih melakukan transaksi keuangan pada lembaga keuangan dibanding meminjam kepada keluarga atau lintah darat. Informan AK-9 mengaku sebelumnya mengatasi masalah keuangan dengan meminjam ke keluarga, namun kendalanya, pinjaman yang diterima tidak mungkin dalam jumlah yang besar. Kini setiap kali membutuhkan pembiayaan, ia selalu memanfaatkan pembiayaan dari KOMIDA.

Di samping dampak positif, keuangan inklusif juga mempunyai dampak negatif yang tak lepas dari imbas persaingan antar lembaga keuangan mikro berbasis perkumpulan mingguan. Selain itu juga karena ketidakseimbangan antara permintaan dan penawaran pembiayaan. Persaingan ini membuat beberapa lembaga keuangan mikro memangkas syarat dan sistem seleksi tanpa memperhatikan dampak negatif yang bisa ditimbulkan, seperti munculnya anggotaanggota bermasalah karena tidak berkomitmen memanfaatkan pembiayaan secara tepat guna. Akibatnya, anggota tidak mampu mengembalikan pembiayaan. Kondisi ini dapat dimanfaatkan anggota bermasalah di KOMIDA dengan tetap berusaha mengembalikan pembiayaan, namun dengan cara yang tidak tepat. Mereka mengajukan pembiayaan pada lembaga keuangan mikro lain yang syaratnya jauh lebih mudah. Kemudahan ini memberi peluang perempuan berpendapatan rendah memanfaatkan pembiayaan dari dua atau lebih lembaga keuangan mikro.

Permasalahan di atas berpotensi memperburuk kondisi perempuan berpendapatan rendah yang terperangkap dalam jebakan utang. Mereka bisa saja memilih skema pengembalian "gali lubang tutup lubang" sehingga kemiskinan tak bisa dihindari. Di KOMIDA masih banyak anggota yang memperoleh manfaat pembiayaan setidaknya dari dua lembaga keuangan mikro. Hal ini bisa terjadi karena tidak adanya larangan tegas terhadap perilaku tersebut. Selama anggota tidak terkendala dalam membayar angsuran pengembalian pembiayaan, maka hal ini tidak akan dipermasalahkan.

\section{Penutup}

Strategi keuangan inklusif KOMIDA ditandai dengan kemudahan akses terhadap keuangan, yaitu dengan memberikan pembiayaan tanpa agunan. Setiap transaksi keuangan dilakukan dalam satu pintu, tepatnya pada saat pertemuan center yang diselenggarakan setiap minggu. Layanan keuangan menjadi minim biaya, tidak ada hambatan jarak dan waktu. Transaksi jauh lebih aman karena dilakukan dekat dengan lokasi rumah yang bersangkutan.

Ketersediaan pembiayaan lebih besar daripada permintaan. Hal ini membuka peluang bagi lebih banyak perempuan yang membutuhkan pembiayaan untuk memulai maupun mengembangkan usahanya. KOMIDA juga melakukan literasi keuangan dengan mengedukasi perempuan berpendapatan rendah untuk rajin menabung, merencanakan masa depan, serta mengelola keuangan. Salah satu syarat pengajuan pembiayaan harus menyertakan rencana penggunaan pembiayaan sebagai bentuk edukasi perencanaan keuangan di masa depan. Sementara syarat peningkatan nominal pembiayaan menjadikan kerajinan menabung dan saldo simpanan anggota sebagai salah satu penilaian.

Penanggulangan kemiskinan melalui strategi keuangan inklusif berjalan efektif serta berkontribusi positif bagi peningkatan ekonomi, kapasitas dan peran perempuan berpendapatan rendah. Sistem seleksi dan monitoring yang memadai adalah kata kunci keberhasilan penanggulangan kemiskinan dan meminimalkan ekses negatif yang muncul sebagai efek samping penerapan strategi keuangan inklusif. Sistem seleksi bisa dinilai sebagai hambatan terhadap inklusi keuangan, namun bila diteliti lebih lanjut, sistem seleksi justru membuat keuangan inklusif menjadi tepat sasaran. Monitoring membuat penggunaan pembiayaan lebih tepat guna dan pengembalian pembiayaan menjadi lebih terjamin. Dampak negatif bisa muncul karena inklusi keuangan bisa disalahgunakan orang yang tidak bertanggung jawab sehingga 
mengakibatkan debt trap dan praktik "gali lubang tutup lubang" yang merugikan dirinya sendiri.

KOMIDA sudah melarang anggota lembaga keuangan mikro lain bergabung menjadi anggota KOMIDA. Namun, belum ada sanksi bagi anggota KOMIDA yang setelah bergabung ketahuan memanfaatkan pembiayaan dari lembaga keuangan mikro lain. Sanksi ini perlu dibuat untuk mengantisipasi dampak negatif seperti praktik "gali lubang tutup lubang" ketika tidak mampu mengembalikan pembiayaan. Dalam rangka menghindari penggunaan pembiayaan untuk keperluan sehari-hari, perlu dilakukan penyesuaian nominal pembiayaan dengan kebutuhan usaha anggota. Hal ini dilakukan supaya jangan sampai anggota menerima pembiayaan yang lebih besar dari kebutuhan riil usaha.

Pemerintah perlu mengevaluasi skema kebijakan keuangan inklusif yang sedang dijalankan. Penyaluran pembiayaan nonpinjaman yang disalurkan kepada golongan masyarakat paling miskin melalui program keluarga harapan maupun kebijakan sosial lainnya memang masih dibutuhkan. Namun, kinerja lembaga keuangan mikro dalam mendukung keuangan inklusif nasional perlu mendapat apresiasi dan perlu juga dipikirkan skema sinerginya dengan pemerintah. Meningkatkan minat usaha perempuan berpendapatan rendah dengan memberikan pembiayaan yang memadai cukup efektif dalam menanggulangi kemiskinan dan memperkuat peran perempuan untuk menyejahterahkan keluarganya. Pembiayaan berbasis pinjaman maupun nonpinjaman perlu dikaji lebih jauh terkait efektivitasnya menanggulangi kemiskinan, tanpa menciptakan ketergantungan.

\section{Daftar Pustaka}

Abdulkadir, M. \& Rilda, M. (2000). Lembaga Keuangan dan Pembiayaan. Bandung: PT Citra Aditya Bakti.

Adams, G. A. \& Rau, B. L. (2011). Putting off tomorrow to do what you want today: planning for retirement. American Psychologist, 66(3), 180.
Badan Pusat Statistik. (2018). Persentase Penduduk Yang Hidup di Bawah Garis Kemiskinan Nasional, Menurut Jenis Kelamin 20152018. Retrieved from https://www.bps. go.id/dynamictable/2019/10/04/1653/ persentase-penduduk-yang-hidup-di-bawahgaris-kemiskinan-nasional-menurut-jeniskelamin-2015-2018.html, on April 30, 2020.

Bank Indonesia. Kamus. Retrieved from https://www. bi.go.id/id/Kamus.aspx, on September 1, 2019.

Bhatia, S. \& Singh, S. (2019). Empowering Women Through Financial Inclusion: A Study Of Urban Slum. The Journal for Decision Makers, 44(4), 182-197. Retrieved from https://remote-lib.ui.ac. id:2158/doi/pdf/10.1177/0256090919897809, on April 20, 2020.

Boon, T. H., Yee, H. S., \& Ting, H. W. (2011). Financial literacy and personal financial planning in Klang Valley, Malaysia. International Journal of Economics and Management, 5(1), 149-168.

Bullock, H. E. (2013). Woman and Poverty: Psychology, Public Policy, and Social Justice. West Sussex: Wiley Blackwell.

Carpena, F., Cole, S., Shapiro, J., \& Zia, B. (2011). Unpacking the causal chain of financial literacy. Policy Research working paper; no. WPS 5798. Washington, DC: World Bank. Retrieved from http://documents.worldbank.org/curated/ en/329301468322465624/Unpacking-thecausal-chain-of-financial-literacy, on April 30, 2020.

Cohen, E. (1984). The sociology of tourism: approaches, issues, and findings. Annual review of sociology, 10(1), 373-392.

Goldberg, M. \& Palladini, E. (2010). Managing Risk and Creating Value With Microfinance. Washington DC: World Bank.

Ife, J. (2013). Community development in an uncertain world: vision, analysis and practice. New York: Cambridge University Press.

Jiang, L., Tong, A., Hu, Z., \& Wang, Y. (2019). The Impact of Inclusive Financial Development Index on Farmer Entrepreneurship. Journal Plos One, 14(5): e0216466. doi: 10.1371/journal. pone. 0216466 .

Kementerian Keuangan. (2012). Press Release KementerianKeuanganHasilKTTG-20.Retrieved from https://fiskal.kemenkeu.go.id/dw-kontenview.asp? $\mathrm{id}=20120622083024508899900, \quad$ on April 30, 2020. 
Kodan, A S. \& Chhikara, K S A. (2013). Theoretical and Quantitative analysis of Financial Inclusion and Economic Growth. Management and Labour Studies, 38(1-2), 103-133. Jamshedpur: School of Business Management \& Human Resources. Retrieved from https://remote-lib.ui.ac.id:2158/ doi/pdf/10.1177/0258042X13498009, on April 30, 2020.

Lusardi, A. \& Mitchelli, O. S. (2007). Financial literacy and retirement preparedness: Evidence and implications for financial education. Business economics, 42(1), 35-44.

Lusardi, A. \& Mitchell, O. S. (2014). The Economic Importance of Financial Literacy: Theory and Evidence. Journal of Economic Literature, 52(1), 5-44. doi: 10.1257/jel.52.1.5.

Mainsah, E., Heuer, S. R., Kalra, A., \& Zhang, Q. (2004). Grameen Bank: Taking capitalism to the poor. Chazen Web Journal of International Business, 1-28.

Mishra, A., Igwe, P., Lean, J., \& Megicks, P. (2014). Supporting micro and small enterprises. In The Routledge Companion to Financial Services Marketing. London: Routledge (Taylor \& Francis Group).

Moleong, L. (2005). Metodologi Penelitian Kualitatif untuk Ilmu-Ilmu Sosial. Bandung: PT. Remaja Rosdakarya.

Neuman, W. L. (2016). Metodologi Penelitian Sosial: Pendekatan Kualitatif dan Kuantitatif. Jakarta: PT Indeks.

Peraturan Presiden tentang Strategi Nasional Keuangan Inklusif (2016).

Pemerintah Kecamatan Cileungsi. (2015). Profil Kecamatan Cileungsi. Retrieved from http:// kecamatancileungsi.bogorkab.go.id, on August 29, 2019.

Sarma, M. (2012). Index of Financial Inclusion - A measure of financial sector inclusiveness. Berlin Working Paper No.07/2012 on Money, Trade, Finance, and Development. Berlin: Competence Center "Money, Finance, Trade and Development". Retrieved from https://finance-andtrade.htw-berlin.de/fileadmin/HTW/Forschung/ Money_Finance_Trade_Development/working paper_series/wp_07_2012_Sarma_Index-ofFinancial-Inclusion.pdf, on August 29, 2019.

Sinaga, S. (2004). Dampak Sosial Kebijakan Pemda DKI Jakarta Tentang Relokasi Pedagang Kaki
Lima di Lokasi Binaan Studi Kasus di Lokasi Binaan Paal Merah Jakarta Pusat. Jakarta: Universitas Indonesia.

Soelaksono, B. (2005). Keuangan Mikro di Indonesia. Lembaga Penelitian SMERU. No.13, 3-10. Retrieved from http:/www.smeru.or.id/sites/ default/files/publication/news13.pdf, on August 29, 2019.

Stynes, D. J. (1997). Recreation Activity and Tourism Spending in the Lake States. St.Paul, MN: North Central Forest Experiment Station.

Suharto, E. (2009). Membangun Masyarakat Memberdayakan Masyarakat. Bandung: PT Refika Aditama.

Tim Publikasi Katadata. (2019). Tingkat Partisipasi Angkatan Kerja Perempuan Indonesia Rendah Dibanding Negara ASEAN. Retrieved from https://databoks.katadata.co.id/datapublish /2019/05/09/tingkat-partisipasi-angkatan-kerjaperempuan-indonesia-rendah-dibanding-negaraasean, on August 29, 2019.

Todaro, M P. (2000). Pembangunan Ekonomi di Dunia Ketiga. Jakarta: Erlangga.

Yaumidin, U K., Suhodo, D S., Yuniarti, P I., \& Hidayatina, A. (2017). Financial Inclusion for Woman: Impact Evaluation on Islamic Microfinance to Women Empowerment in Indonesia. Financial Inclusion and Poverty Alleviation, 81-140. Retrieved from https:// remote-lib.ui.ac.id:2069/content/pdf/10.1007 \%2F978-3-319-69799-4_3.pdf, on August 29, 2019. 